\title{
10 Performance evaluation of bread wheat varieties
}

\author{
Melle Tilahun and Wondimu Bayu
}

\section{Introduction}

Bread wheat is one of the most staple food crops in the world and one of the most important cereals cultivated in Ethiopia. Ethiopia is the largest wheat producer in sub-Saharan Africa with 1.1 million hectares (ha) of cultivated land. In Ethiopia, wheat is the third most important crop after teff and maize. Wheat comprises about 14.64 per cent of the total land devoted to cereal; it is produced on 1.68 million ha of land, from which 3.076 million tons are obtained at national level (Gebremariam et al., 1991). Wheat is widely grown in the Amhara region; it covers 548,315 ha of land and yielded 896,093 tons in the region in 2010, which is 29 per cent of the total national production (CSA, 2010). It is grown in the highlands at altitudes ranging from 1,500 to 3,000 metres above sea level situated between $6-16^{\circ} \mathrm{N}$ and $35-42^{\circ} \mathrm{E}$. However, the most suitable agro-ecological zones for wheat production fall between 1,900 and 2,700 metres above sea level (Gebremariam et al., 1991).

This low productivity is mainly due to disease and pests, low-yielding varieties, frost, poor soil fertility and lack of full or supplemental irrigation (SI). Ethiopia has a large potential of water resources that could be developed for irrigation. Despite this, the country continues to receive food aid to about 10 per cent of the population who are at risk, annually, out of seventy million (Gebremariam et al., 1991). The government is committed to solving this paradox through an agricultural led development programme that includes irrigation scheme development as one of the strategies. In order to increase total production, new wheat cultivars should be tested for different agroecologies and locations. The performance of a new variety depends upon its yield and adaptation potential in different locations.

Participatory varietal evaluation and selection is being conducted for many crops such as rice (Sthapit et al., 1996), common bean (Kornegay et al., 1996) and barley (Ceccarelli and Grando, 2007; Fufa et al., 2010). Courtois et al. (2001) evaluated the effect of participation by farmers by comparing only the rankings of varieties by farmers and breeders at the same locations; they reported a strong concordance between farmers and breeders in environments that have been producing contrasting plant phenotypic performance in rice. Farmers' selection 
criteria vary with environmental conditions, traits of interest, ease of cultural practice, processing, use and marketability of the product and ceremonial and religious values. Creating an option and access to farmers in vertisol was the priority of this research.

\section{Objectives}

The objectives were to:

- $\quad$ evaluate and identify adaptive, high-yielding and disease-resistant bread wheat varieties with the participation of farmers;

- to identify farmers' selection criteria; and

- to empower farmers in a participatory variety selection process.

\section{Materials and methods}

\section{Description of the study area}

The experiment was conducted in 2010 in the Gumara-Maksegnit watershed in the highland area of northern Ethiopia. The watershed is found in the north Gondar administrative zone of Amhara region and is located about $45 \mathrm{~km}$ south-west of Gondar town. It covers an area of 56 square km between $12^{\circ} 23^{\prime} 53^{\prime \prime}$ to $12^{\circ} 30^{\prime} 49^{\prime \prime}$ north latitude and $37^{\circ} 33^{\prime} 39^{\prime \prime}$ to $37^{\circ} 37^{\prime} 14^{\prime \prime}$ east longitude (Figure 10.1).

Altitude within the watershed ranges from 1,923 to 2,851 $\mathrm{m}$ above sea level. The study area is characterized by a bi-modal rainfall distribution with an annual mean value of $1,052 \mathrm{~mm}$. The mean minimum and maximum temperatures are 13.3 and $28.5^{\circ} \mathrm{C}$ respectively. The study area is characterized by different soil types such as red soil covers 21 per cent (nitosol), black soil 43 per cent (vertisol) and brown and other types (gleysol and leptsol) cover 36 per cent. The textural composition of the soil $(0-25 \mathrm{~cm})$ was found to be sandy loam, loam, clay loam and clayey; they constitute 6.7 per cent, 52.7 per cent, 20.5 per cent and 20.1 per cent respectively.

Farming in the watershed is mixed crop-livestock subsistence farming. The major crops include teff, sorghum, bread wheat, garlic, shallot, faba bean, lentil, chickpea, field pea, linseed, finger millet, noug, barley and maize. Teff, sorghum and chickpea are the main staple crops in the study area. Vegetation is part of the evergreen dry afromontane forests that dominate the highlands of Ethiopia.

Human activities have increasingly modified the land use condition of the area over time. Currently there are different land use types such as cultivation, grazing and settlement. Mixed farming is the predominant activity in the study area; i.e. crop production and livestock rearing ( 90 per cent). The average landholding size is 1.33 ha per household. Due to population increment, cultivable land per family has declined over time and communal grazing and forest lands 


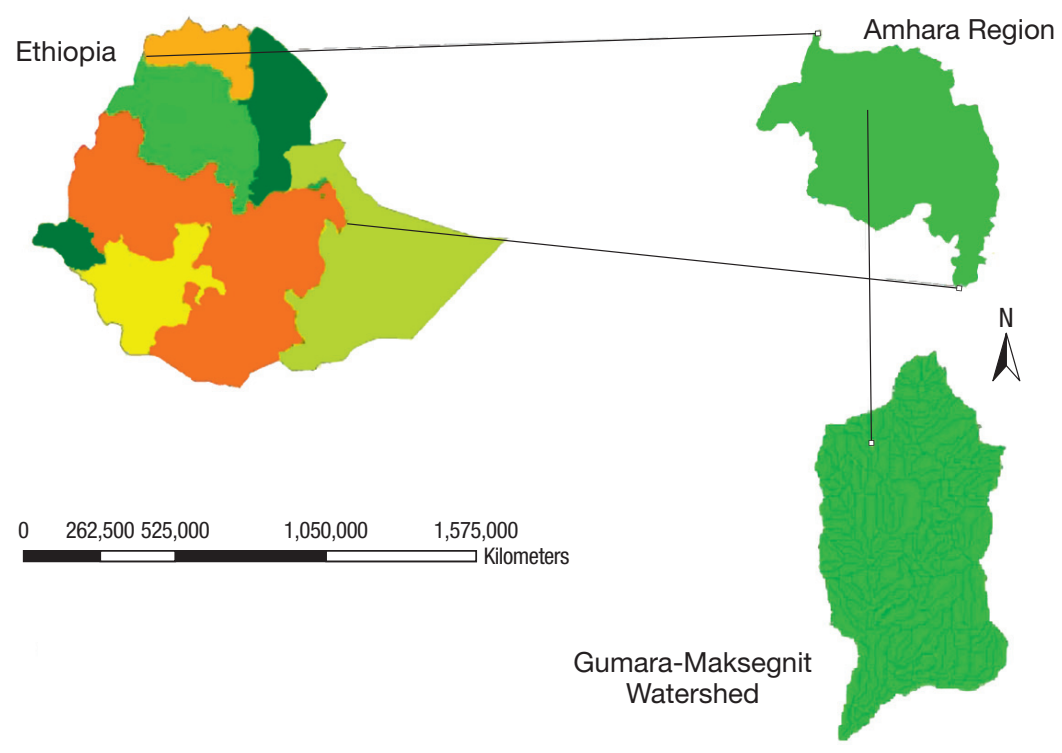

Figure 10.1 Map of the study area

are being converted to arable lands and settlements. The area is characterized by terminal moisture stress.

\section{Methodology}

Fourteen released bread wheat varieties were tested at the vertisols of the watershed for their suitability to the Gumara-Maksegnit area of Amhara region. The trial was conducted using randomized complete block design (RCBD) with three farmers' sites as replications. Planting was done by row planting at a seed rate of $150 \mathrm{~kg} / \mathrm{ha}$. Fertilizer was applied at the rate of $41 / 46 \mathrm{~kg} / \mathrm{ha} \mathrm{N}$ and $\mathrm{P}_{2} \mathrm{O}_{5}$ respectively. Half of the total nitrogen and all phosphorus was applied at the time of planting while the remaining nitrogen was applied at the time of tillering. To reduce border effects, data was recorded from the central rows. Weeding and other management practices were done as per recommendation. A farmers' research and extension group (FREG) was established with a membership of forty farmers. The FREG consists of men and women, poor and rich, young people and elderly people.

\section{Statistical analysis}

Analysis of variance, for all the characters and comparisons of methods of treatment, were made following Duncan's new multiple range test and SAS statistical software (SAS, 2002). Spearman rank correlation was used to compute the correlation coefficient between farmers' and breeders' scores. 


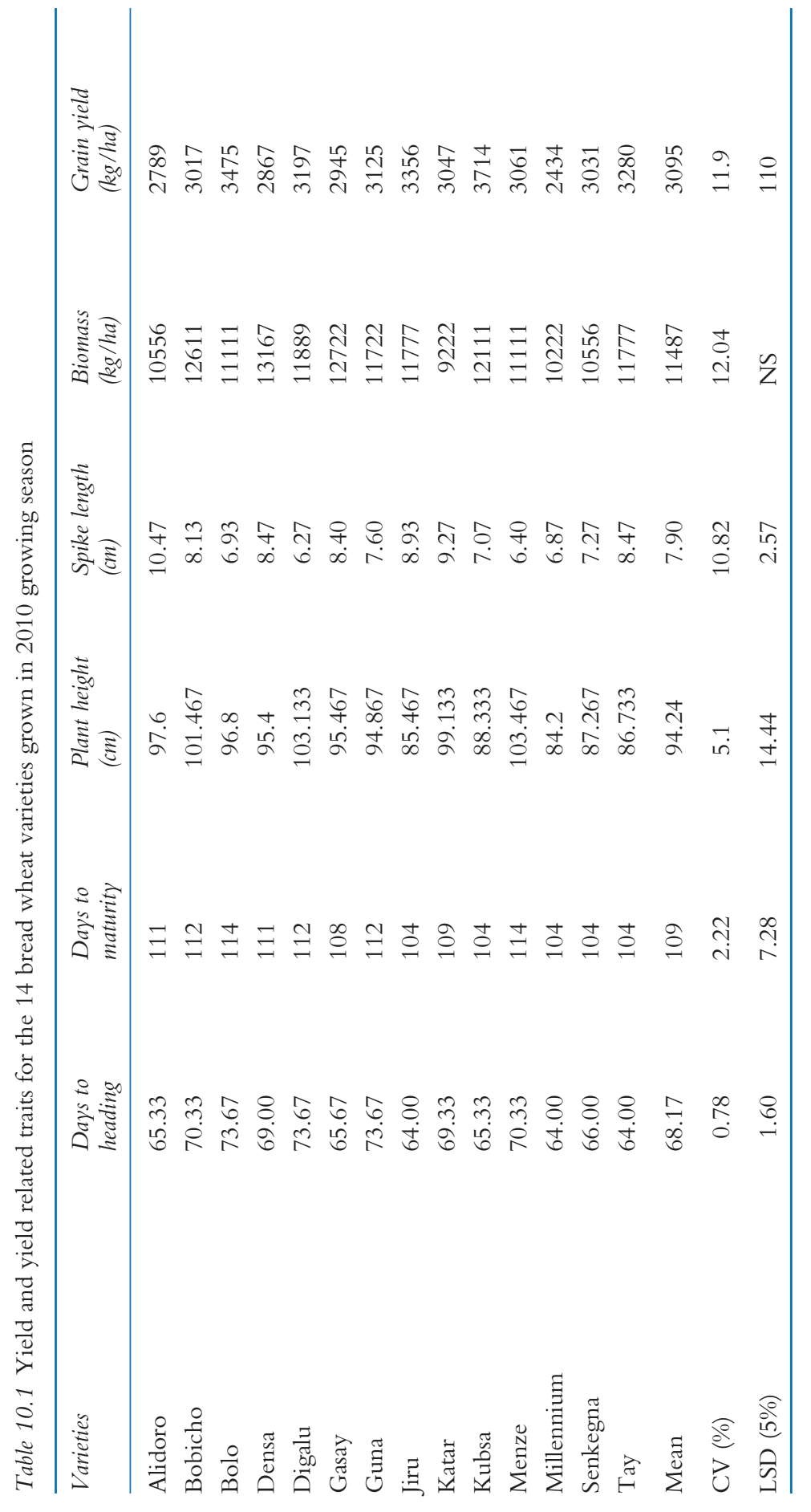




\section{Results and discussion}

Pooled analysis of variance revealed a highly significant difference $(P \leqslant 0.01)$ among the varieties in parameters of plant height, spike length, days to heading, days to maturity and grain yield. However, statistically significant difference was not observed in biomass weight (Table 10.1). Statistical difference in grain yield was observed only between the variety Kubsa and Millennium; the rest are not significant as shown in Table 10.1. The highest grain yield was recorded in Kubsa $(3,714 \mathrm{~kg} / \mathrm{ha})$, followed by Bolo and Tay which gave 3,475 kg/ha and 3,280 $\mathrm{kg} /$ ha respectively. However, Kubsa was not selected due to its susceptibility to yellow rust. The highest plant height was recorded from the variety Menze $(103.5 \mathrm{~cm})$ and the shortest was from Millennium $(84.2 \mathrm{~cm})$. The variety Alidoro had the longest spike and the variety Digalu had the shortest. The range of flowering of the varieties was between sixty-four and seventy-three days.

Table 10.2 Results of farmers' evaluation on varieties at maturity of bread wheat

\begin{tabular}{|c|c|c|}
\hline Variety & Evaluation & Decision \\
\hline Bolo & $\begin{array}{l}\text { Late maturing and thus not suitable for double } \\
\text { cropping, small spike, thin stem and thus } \\
\text { susceptible for lodging }\end{array}$ & Rejected \\
\hline Katar & $\begin{array}{l}\text { Late maturing, small spike, poor tillering, lacks } \\
\text { uniformity in heading }\end{array}$ & Rejected \\
\hline Tay & $\begin{array}{l}\text { Early maturing, tall, big spike, large number of } \\
\text { tillers with thick stem, large biomass, large yield } \\
\text { is expected }\end{array}$ & First \\
\hline Guna & Late maturing, poor tillering, small spike & Rejected \\
\hline Alidoro & $\begin{array}{l}\text { Medium maturing, big spike, large biomass, } \\
\text { good tillering. Ranked third because of its } \\
\text { relative late maturity }\end{array}$ & Third \\
\hline Densa & Late maturing, big spike, good biomass & Rejected \\
\hline Gasay & $\begin{array}{l}\text { Late maturing, good biomass, big spike, } \\
\text { uniform heading }\end{array}$ & Fifth \\
\hline Menze & $\begin{array}{l}\text { Very late maturing, leafy, small spike, poor yield } \\
\text { is expected }\end{array}$ & Rejected \\
\hline Bobicho & $\begin{array}{l}\text { Small spike, thin stem and thus susceptible for } \\
\text { lodging, has leaf disease (blotching) }\end{array}$ & Rejected \\
\hline Kubsa & $\begin{array}{l}\text { Early maturing, big spike, thick stem, productive } \\
\text { tiller }\end{array}$ & Second \\
\hline Jiru & $\begin{array}{l}\text { Early maturing, tall, big spike, thick stem, } \\
\text { uniform heading }\end{array}$ & Fourth \\
\hline Digalu & Very late maturing, very weak in all aspects & Rejected \\
\hline Senkegna & Weak/thin spike, thin stem, uniform heading & Sixth \\
\hline Millennium & $\begin{array}{l}\text { Uniform heading, thick stem, weak/thin spike, } \\
\text { large biomass }\end{array}$ & Seventh \\
\hline
\end{tabular}


The Spearman rank analysis showed significant $(P \leqslant 0.01)$ correlation between farmers' selection and grain yield. The farmers' selection scores were significantly and positively correlated with grain yield with correlation coefficients of (0.737). The results of this study showed that farmers were as efficient as breeders in identifying high-yielding varieties with desirable traits for their specific environment. Similar results were found by Sthapit et al. (1996) and Fufa et al. (2010). This may be due to the main selection criteria of farmers and breeders based on final grain yield. Among varieties, Tay matured early compared to other varieties which will best fit the early bread wheat production system. The varieties preferred by farmers at maturity stage during field evaluation were Tay and Bolo. The Spearman rank correlation analysis also indicated the presence of a statistically significant $(P \leqslant 0.01)$ correlation between farmers' selection with the objectively measured quantitative trait (grain yield) and breeders' selection. This indicated that grain yield was the main selection criteria for farmers and farmers were as competent as breeders in varietal selection (Table 10.2). Farmers' selection criteria were waterlogging resistance, uniformity in terms of stand and maturity, spike length, tillering capacity, disease reaction and seed colour. This is in agreement with the findings of Fufa et al. (2010). According to Courtois et al. (2001), the presence of significant positive correlation between breeders and farmers reduces the benefits of farmers in varietal selection process. Therefore, based on farmers' preferences, breeders' selection, grain yield and resistance to yellow rust, the varieties Tay and Jiru are recommended for production in the GumaraMaksegnit watershed and similar areas.

\section{Conclusion and recommendations}

The overall performance of varieties was promising. The mean value of grain yield ranged from 2,434 $\mathrm{kg} / \mathrm{ha}$ (Millenium) to $3,714 \mathrm{~kg} / \mathrm{ha}$ (Kubsa). Participatory varietal selection has a significant role in technology adaptation and dissemination in a shorter time than conventional approaches. Farmers' selection criteria were resistance to waterlogging, uniformity in terms of stand and maturity, spike length, tillering capacity, disease reaction and seed colour. Based on farmers' preference, grain yield, days to maturity and yellow rust resistance, the varieties Tay and Jiru are recommended for the GumaraMaksegnit watershed and similar areas with their full production packages.

\section{References}

Ceccarelli, S. and Grando, S., 2007. 'Decentralized-participatory plant breeding: an example of demand driven research'. Euphytica, 155: 349-60.

Central Statistical Agency (CSA), 2010. 'Agricultural sample survey 2009/10. Report on area and production of crops (private peasant holdings, Meher season)'. CSA, Vol IV, Addis Ababa, Ethiopia. 
Courtois, B., Bartholome, B., Chaudhary, D., McLaren, G., Misra, C.H., Mandal, N.P., Pandey, S., Paris, T., Piggin, C., Prasad, K., Roy, A.T, Sahu, R.K., Sahu, V.N., Sarkarung, S., Sharma, S.K., Singh, A., Singh, H.N, Singh, O.N, Singh, N.K., Singh, R.K., Singh, S., Sinha, P.K., Sisodia, B.V.S. and Takhur, R., 2001, 'Comparing farmers' and breeders' rankings in varietal selection for low-input environments: a case study of rainfed rice in eastern India'. Euphytica, 122: 537-50.

Fufa, F., Grando, S., Kafawin, O., Shakhatreh, Y. and Ceccarelli, S., 2010. 'Efficiency of farmers' selection in a participatory barley breeding programme in Jordan'. Plant Breeding, 129: 156-61.

Gebremariam, H., 1991. 'Bread wheat production and research in Ethiopia' in H. Gebremariam, D.G. Tanner and M. Huluka (eds), Bread wheat research in Ethiopia: a historical perspective (pp. 1-16). Addis Ababa, Ethiopia.

Kornegay, J., Beltran, J.A. and Ashby, J., 1996. 'Farmer selections within segregating populations of common bean in Colombia: Crop improvement in difficult environments' in P. Eyzaguirre and M. Iwanaga (eds), Participatory plant breeding (pp. 151-9). Proceedings of a workshop on participatory plant breeding, 26-9 July 1995, Wageningen, Netherlands.

SAS Institute, 2002. 'SAS System for Windows Release 9.2'. SAS Institute, Cary, NC. SPSS, 2003. 'SPSS for Windows Release 12.0.1'. SPSS, Chicago, IL.

Sthapit, B.R., Joshi, K.D. and Witcombe, J.R., 1996. 'Farmer participatory crop improvement. III. Participatory plant breeding, a case study for rice in Nepal'. Experimental Agriculture, 32: 479-96. 